\title{
実験的閉塞性黄疸および肝循環障害における血清と 胸管リンパ液組成の変動に関する研究
}

\author{
岡山大学医学部第一外科学教室（指導：折田葶三教授）
}

上田祐造

(平成 4 年 4 月 14 日受稿)

Key words : 実験的肝障害, 閉塞性黄疸, 肝循環障害, 胸管リンパ液, 胸管カヌレーション

緒言

肝の異常な条件下では，腹水の出現をはじめ としてきまぎまな病態像がみられることは周知 のことである.

肝の病的状態には, 直接的, 間接的な腹胿内 リンパ動態が関与している。そしてリンバ動態 を観察することは肝の病態像の一指標になると 考えられるが，そのリンパ動態を知る手段とし て胸管リンパの検索がある.

胸管には，右頸部，右上肢，胸部リンパの一 部を除く, 全身リンパ液の $98 \%$ 以上が流入する ${ }^{28)}$ が, 主なものは,

i）腸管由来の腸リンパ液

ii）肝由来の肝リンパ液

.iii）下肢, 腰部からの腰リンパ液

である.このうちもっとも多いものは，腸りン パ液で, その量は胸管リンパ流量の約 $2 / 3$ 占め, 次いで肝リンバ液が1/2〜1/4を占めるといわれて いる ${ }^{10,17,25,60)}$. 肝リンパ液は肝小葉内の類洞と肝 細胞との間に存在する空隙－Disse 腔において 生成されると考えられている.この Disse 腔の 内圧は, 正常の状態下では, 肝類洞圧と同様に きわめて低く, 類洞圧の上昇につれて, Disse 腔 での肝リンバ生成量が増加する. 肝動脈もその 終末の細小分枝は類洞内に注 (゙79)といわれている が, 肝動脈血流を減少あるいは消失させた場合

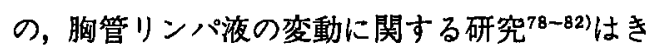
わめて少ない. LAUFMAN ${ }^{80)}$ はイヌの下大静脈狭窄 (McKee 犬) 作成後 2 週目に肝動脈を狭窄する と, 門脈圧は20.6 $\mathrm{cmH}_{2} \mathrm{O} よ り 18.5 \mathrm{~cm} \mathrm{H}_{2} \mathrm{O}$ に低
下し，さらに結森すると $14.4 \mathrm{cmH}_{2} \mathrm{O}$ に低下し， 腹水は McKee 犬に比較して遅くあらわれ，し かも腹水の継続期間も短いことをみている.

門脈圧六進症と胸管リンパ液に関する研

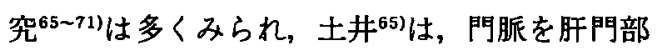
で狭窄したイヌでは, 門脈圧上昇に比例して胸 管リンパ流量は增加し, 狭宣を解除して, 門脈 圧を正常值に複帰させると，その直後に著しい 増量をみせた後, 正常リンパ流量にもどること をみている。このリンパ流量の変化は，門脈を 一時的に完全遮断するときには, 胸管りンパ液 の增量はなく，15分後に門脈うっ滞を解除する と約 3 倍量に達する一時的增加（5 分間隔のリ ンパ液採取)をみせたと述べている. WITTE よると, 急性門脈狭窄犬では150分の間, 胸管リ ンパ流量は增加していない.

次に下大静脈狭䇤については, 1894年 S TARLING ${ }^{120}$ が, 胸腔内下大静脈狭窄が胸管リンパ 流量を増加さすこと，またその増加したリンパ 液の大部分はうっ血した肝で生成されることを 実験的に示して以来, 腹水と肝リンパとの関連 についてなされた研究は数多い9,15 27).

胆道閉塞時の肝病態像については, D $\mathrm{UMONT}^{3 \mathrm{6} \sim 43}$ によると, 実験的胆道閉塞作成後の胸 管リンパ液中には, 胆道閉塞後 1.5 時間でビリル ビン $(3 \mathrm{mg} / \mathrm{dl})$ が出現し, 以後 5 時間目まで増 加し,一方血清中には 3 時間目に出現 $(2 \mathrm{mg} / \mathrm{dl})$ したと述べ，肝リンパへの胆汁色素流入がきわ めて早期におこることを指摘している. また結 䅨した総胆管内に注入したマイクロバリウムが 肝リンパ管に出現することをみた報告84)もある。 
以上のごとく肝循環の異常ならびに胆道閉塞 の状態によって出現するさまざまな肝の変化と, その結果生ずる胸管りンパ液の物理的, 生化学 的変動を追求することは，肝の循環異常ならび に胆道閉塞を生ずる疾患の病態を理解し，それ に对処する上で重要なことと考えられる．とこ ろでこの胸管リンパ液の検索を行うために同一 個体から継続的に長期間リンパ液を採取した報

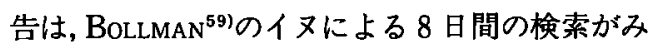
られるのみで他に例をみない.そこで著者は二, 三の工夫を行ってイヌを用いて長期間の胸管リ ンパ液採取を可能にした上, 実験的肝の循環異 常および胆道閉塞を作成し，その胸管リンパ液 を 3 週間にわたって経日時的に採取して得られ た実験結果を報告する。

\section{実 験 方 法}

\section{1. 実験動物}

体重15 25kgの健康な雑種成犬を用いた．実 験犬は当日のみ絶食として,ネンブタール0.5ml/ $\mathrm{kg}$ による静脈麻酔を施行し必要に応じて（開胸 操作を要する場合) 気管内挿管を行い, 空気に よる陽圧人工呼吸下で頸部および腹部操作を行 った (図 1). 実験中は麻酔剂を適宜追加投与し, 適当量の補液（リンゲル液 $10 \mathrm{ml} / \mathrm{kg} /$ 時）と抗生 剂 (ABPC $20 \mathrm{mg} / \mathrm{kg}$ 静注) の投与を行った. 術後 にも，水分搨取の少ないイ邓や術中比較的出血 量の多かったイヌには $2 \sim 3$ 回，全量300～500 $\mathrm{ml}$ の補液を行い，また術後 3 日目まで抗生剂を 投与した.

\section{2. 手術手段}

1）胸管内挿管法

イヌを左頸部伸展位に固定し(図 1)，左頸部 に約 $6 \mathrm{~cm}$ の縦切開をおき, 左静脈角に流入する 胸管を求め(このさい, 外頸静脈は二重結係し て切離し, 手術操作の便をよくした),この部で 逆行性に, 胸管に外径 $2.3 \mathrm{~mm}$ (内径 $1.5 \mathrm{~mm}$ ) のポ リビニールチューブを約 $2 \mathrm{~cm}$ 择入し, 周辺組織 に縫着固定した。一方, 同じ径のチューブを外 頸静脈より前大静脈内に㨂入固定し，この 2 本 のチューブを体外にて連結した(図2). 胸管内 挿管の成功率は $90 \%$ であった. 胸管内チューブ からはリンパ液が絶えず流出するので，金属製
のU字管を用いて外頸静脈内チューブと連結し た.こうして平常は胸管リンバ液を自然に近い 状態で大静脈系に流入させておき，必要に応じ てリンバ液採取を行うことができた。

\section{2) 門脈内指管法}

アトムの延長チューブを用いた（外径 $2 \mathrm{~mm}$ ）。 捜管は頸部操作の終了後に, 開腹して, 上腸間 膜静脈の分枝より行った. 先端を門脈本幹に誘

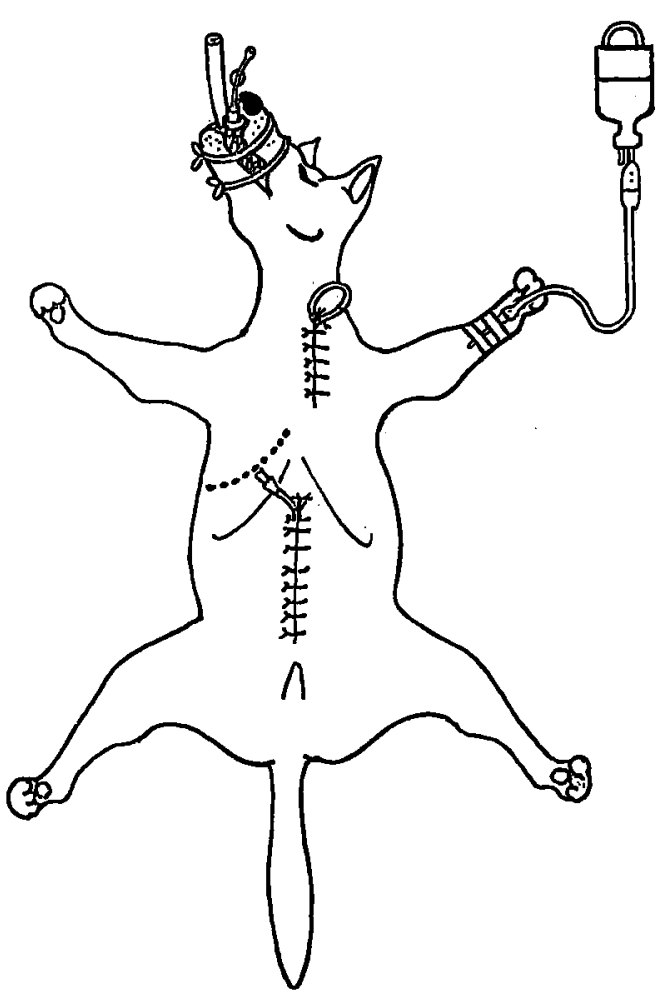

図 1 手術図

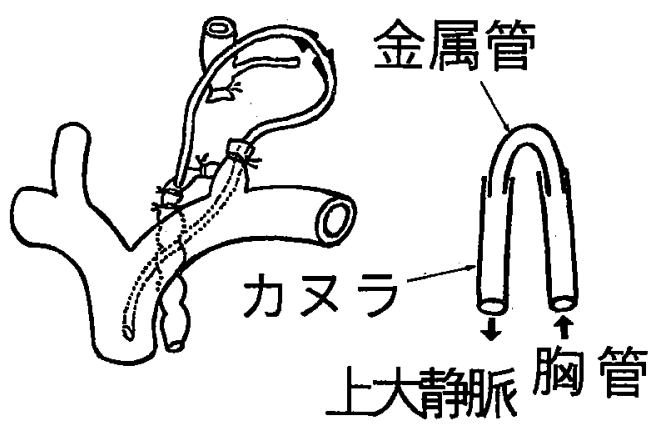

図 2 胸管挿管の方法とコネクター 
導したチューブは皮下トンネルを通じて腹壁外 八出した。この門脈内チューブにより, 次回の 静脈麻醉や抗生剂の投与,採血が簡便に行えた. チューブにはへパリン加生食水を常にみたして おいた。

\section{3）チューブ保全法}

頸部と腹部のチューブを長期間抜去させない ようにするために，手術終了後ジャケット型ギ プスを装着した（図 3)。このさい，前肢の運動 が可能であるように留意した。チューブは, 頸 部では包带でギプスにく、クつけ，腹部ではギ プスの中に入れ，食物（日本クレア製飼料）捸 取と充分な運動を可能にした.

3 . 検索項目

術後 3 週間, 経日時的に, 胸管リンパ流量, 門脈圧，血清および胸管リンパ液中の総コレス テロール值, GPT 值, 総ビリルビン值, アルカ リフォスファターゼ值, ZTT 值, 総蛋白量を測 定し, 比較検討した。

1）胸管リンパ流量

諸種の条件でリンパ流量は容易に変動するの で, 実験条件の変化が非とんどないと考之られ る急性門脈遮断実験では, 胸管リンパ液採取を 10分間隔とし，他の 4 つの長期観察実験群では 30分間隔という比較的長い間隔で測定した。

2 ) 門脈圧, 中心静脈圧

門脈圧，中心静脈圧は水平背面を基準として 水柱マノメーター法により測定した。

3）血清拉よび胸管リンパ液の成分

総コレステロール值, GPT 值, 綕ビリルビン 值, アルカリフォスファターゼ值, ZTT 值は中 外製 RABA 测定器を用いた，総蛋白量の測定 は日立蛋白計を用いた。

\section{4. 実 験 群}

胸管内チューブ留置後, 開腹または開胸によ $\eta$, 肝の循環障害実験として, 次の 4 群を作成 した．肝門部の操作にあたってはできる限りリ ンパ管や，小血管の損傷をおこさないように留 意した。

1) 門脈狭窄群（5頭）

腹部正中切開にて開腹, 肝十二指腸靱带を鋭 的に $1 \sim 1.5 \mathrm{~cm}$ 縦切開し, 門脈本幹を露出して門 脈テープによる狭窄を行った。 そのさい門脈の
外径を約 $2 / 3$ 狭窄させた。この狭察で門脈圧は 10〜 $15 \mathrm{~cm}$ 上昇した. 門脈圧の上昇が $20 \mathrm{~cm}_{2} \mathrm{O}$ 以 上になるとイヌは早期に死亡した.

附・急性門脈遮断実験群（3 頭）

門脈狭窄群と同様の方法で門脈本幹の完全結 紫を行った。

2) 総胆管結紫群 ( 5 頭)

肝十二指腸勒带内で十二指腸にできるだけ近 く総胆管を露出し, 二重結森の上, 切離した.

3) 肝動脈結紮群 ( 5 頭)

肝十二指腸鞅帯内で総肝動脈より分枝する固 有肝動脈を二重結禁し，胆のう壊死をさけるた め胆摘を付加した。

4) 胸部下大静脈狭窄群 (McKee群, 5 頭)

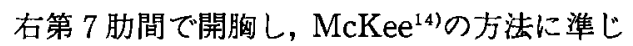
て下大静脈（解剖学的には後大静脈）の狭窄を 行った. 横隔膜上約 $5 \mathrm{~cm}$ の部で下大静脈に門脈 テープをかけ，外径を約1/3に狭窄した。この操 作により狭窄部直下の中心静脈圧は $5 \sim 10 \mathrm{~cm}$ $\mathrm{H}_{2} \mathrm{O}$ 上昇した.

\section{実 験 成 績}

\section{1. 胸管リンパ流量の経時的変動}

術前值はほぼ $20 \mathrm{ml} / 30$ 分であった.急性門脈遮 断群（図 4) では, 術直後より腸管系, 脾, 腸 間膜のうっ血, 浮腫, チアノーゼが著明となり， この状態で10分間隔の胸管リンパ流量変動をみ ると, 術直後より 1 時間の間, 術前值の $5 \sim 8$ 倍の高流量を示した，その後急速に流量が減少 し, 約 3 時間後には術前值に復し,さらに減少

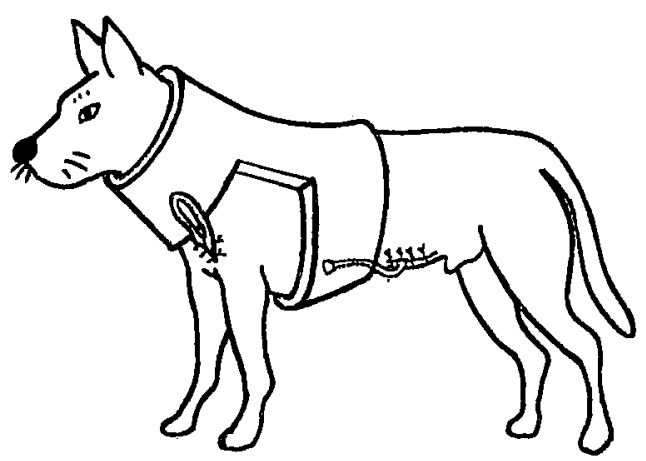

図 3 ジャケット型ギブス装着（ギブスの上から包 带をまく) 
し続けて，補液や，抗生剂を投与しても $4 \sim 5$ 時間で死亡した，死亡までに放流された全リン パ液は約250mlであった。この実験中，採取した 胸管リンパ液をできるだけ忠実に大静脈内にか えした症例（ー印）も，リンパ夜を放流した症 例も胸管リンパ流量，死亡までの経過時間には ほとんど差を認めなかった。胸管りンパ液はこ の実験犬の心停止後もなお約 30 分間にわたり， 少量ながら自然に流出した. 門脈遮断群の胸管 リンパ流量の経時的変化は, 後述の門脈㹨䆣群 の経日的変化と同様の傾向を示した. また急性 門脈遮断群における GPT, Al-P, 総コレステロ 一ル值, 総ビリルビン值 (血清中) の変動は比 較的小さかった(図 5). 次に肝循環障害作成後 長期間観察した実験群（困 6）の胸管リンパ流 量 (30分間隔) をみると, 門脈狭窄群では直後 に約 3 倍の高値となった，胆道結禁群では結禁 直後より增加して 2 日後には術前値の約 3 倍に 達した. 門脈狭窄群と胆道結禁群はその後 $2 \sim 3$ 週にかけ潮減し， 3 週目に術前值に復した。肝 動脈結紮群では 3 日目に術前値のほぼ 2 倍に增 量したが，1週目には術前值に復し，その後も ほとんど変動しなかった. McKee 群の胸管リン パ流量のふえ方は特街的で，術直後には増加せ ず，2 日目に 2 倍， 8 日目には 4 倍と増量して 2 週目には $6 〜 7$ 倍量ときわめて高値を示した がその後 3 週目にかけて軽度隇少した. 最高 160 $\mathrm{ml} / 30$ 分であったが, 3 週目でもなお $130 \mathrm{ml} / 30$ 分 という流量を示す個体もあった。

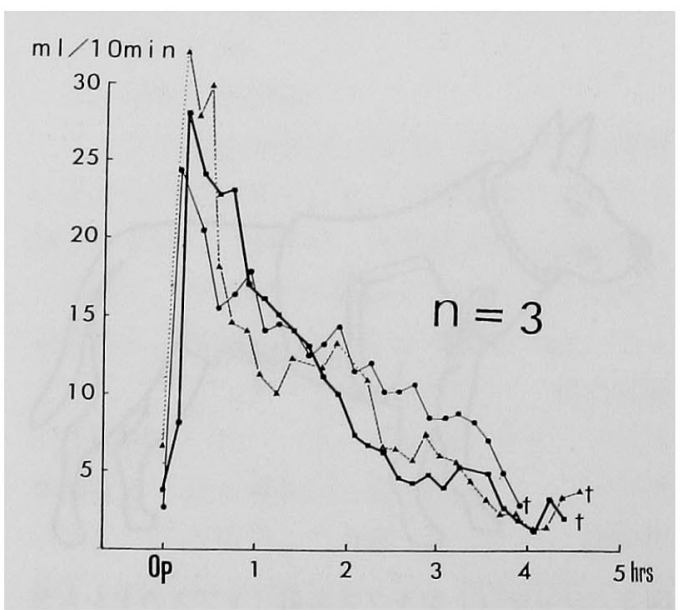

図 4 急性門脈遮断群の胸管リンパ流量 (TDF)

\section{2. 門脈圧の経時的変動（図 7)}

門脈圧は胆道結禁群および肝動脈結紮群では ほとんど変動せず，わずかに胆道結染群で術後 $2 ， 3 ， 4$ 日目にかけ最高 $5 \mathrm{~cm} \mathrm{H}_{2} \mathrm{O}$ 程度の增加 をみたのみであった．門脈狭寯群と McKee 群 では術後 2 週間にわたり高值を持続した。しか し 3 週目には減少した. すなわち門脈結紮群で

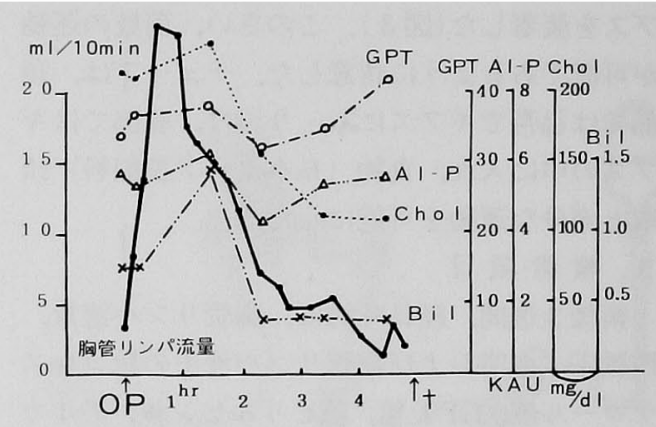

図 5 急性門脈遮断群の血清生化学値

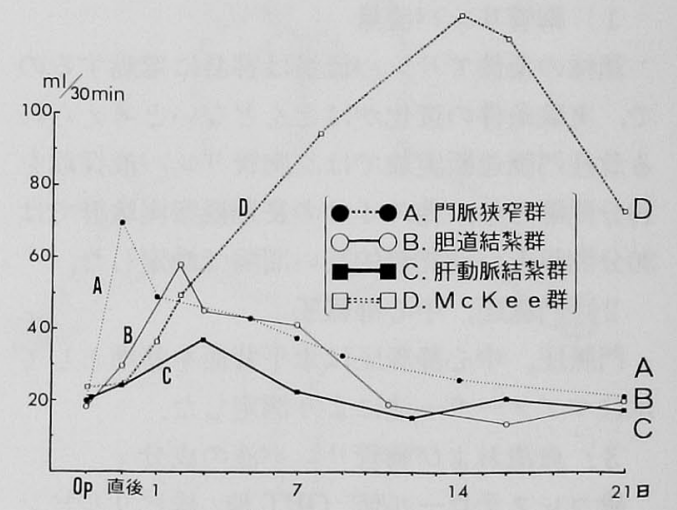

図 6 各群の胸管リンパ流量

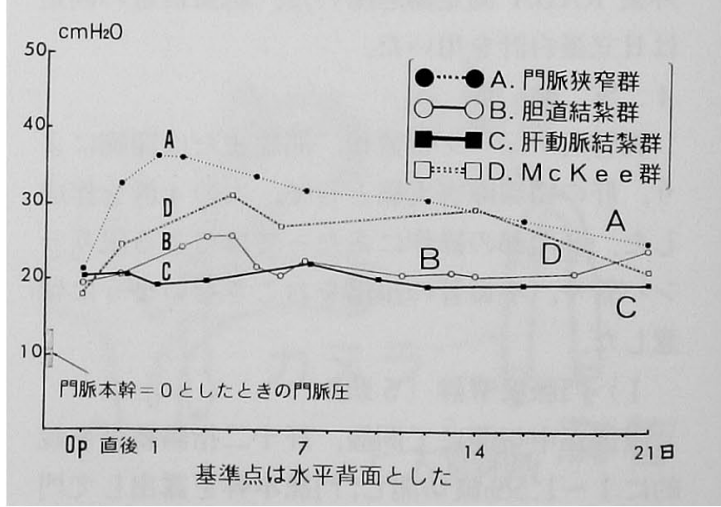

図 7 各群の門脈圧 (PVP) 
は術後 1 日目から 2 日目にかけ術前值よりも約 $15 \mathrm{~cm} \mathrm{H}_{2} \mathrm{O}$ 増加して $37 \mathrm{cmH}_{2} \mathrm{O}$ となり，2 週目で $30 \mathrm{cmH}_{2} \mathrm{O}$ となり， 3 週目には $25 \mathrm{cmH}_{2} \mathrm{O}$ に減少 した. McKee 群でも術後 4 日目 $30 \mathrm{cmH}_{2} \mathrm{O}$ に上 昇したが 3 週目にはほほ術前値に復した。

3. 血清および胸管リンパ液成分の経時的変動

1) 紷コレステロール值（図 8，9）

胸管リンパ液中の総コレステロール值は, す べての実験群で $100 \mathrm{mg} / \mathrm{dl}$ 以下と血清中に比し $1 / 2$ 程度の低值を示し，血清中における経時的変動 が胸管リンパ液中に比し大きい。

血清中では各群とも術後早期に一過性に $50 \mathrm{mg} /$ $\mathrm{dl}$ 程度増加したが, その後 $200 \mathrm{mg} / \mathrm{dl}$ 以上に増加 したものは胆道結禁群のみであった. 胆道結紮 群では 2 週間にわたり $250 \mathrm{mg} / \mathrm{dl}$ 程度の高值を示 したが 3 週目には $180 \mathrm{mg} / \mathrm{dl} に$ 減少した。それで もなお他の群に比し高値であった，肝動脈結紮 群では術後 1 日目に $150 \mathrm{mg} / \mathrm{dl}$ に上昇した後, 軽 度変動し, McKee 群では 3 日目に術前值に復し た.

胸管リンパ液中の総コレステロール值は，胆

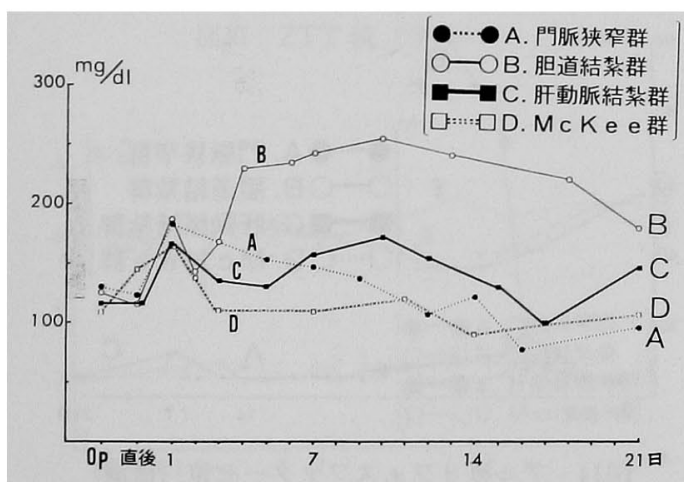

図 8 総コレステロール值（血清）

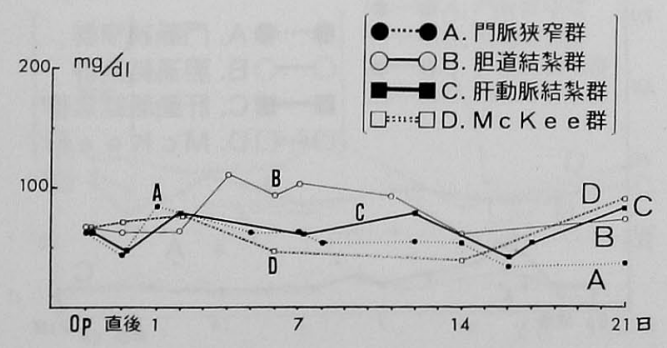

図 9 綕コレステロール值 (リンパ)
道結染群で 4 日目より 2 週目にかけて $100 \mathrm{mg} / \mathrm{dl}$ 程度の比較的高值を示したのみで他の三群はす へへてほとんど変動しなかった。

2) GPT 值（困10,11)

血清中では, 門脈狭定群はほとんど無変化で, 胆道結紧群は術後次第に上昇し， 2 週目には $270^{\mathrm{KU}}$ と高值を示し， 3 週目にかけてその高值が 持続した. 肝動脈結紮群では術後急上昇し， 3 日目で最高值となり以後減少し 8 日目には $90^{\kappa \mathrm{KU}}$ 程 度になりその值が 3 週目まで持続した。術後 2 週にわたり漸増した胆道結紮群と, 術後急上昇 しその後急減した肝動脈結紮群の曲線とは図10 のごとく，ほほ 1 週目に $150^{\mathrm{kU}}$ の值で交叉した。 McKee 群は 8 日目まで上昇 $\left(150^{\mathrm{KU}}\right)$ し，その 後減少して 3 週目には術前值に復した.

胸管リンバ液のGPT 值は門脈狭窄群, McKee 群で,ほぼ同様の変動を示し, 術後 2 日目に $80^{\mathrm{KU}}$ まで上昇したがその後徐々に減少し 3 週目には 術前值に復した。胆道結㮡群では血清 GPT 値と 同様に徐々に上昇した。

胆道結紮群と肝動脈結紮群の胸管リンパ液中 GPT 值も血清中と同様に変動曲線が交叉した.

GPT 值の最高值も胸管リンパ液, 血清中とも
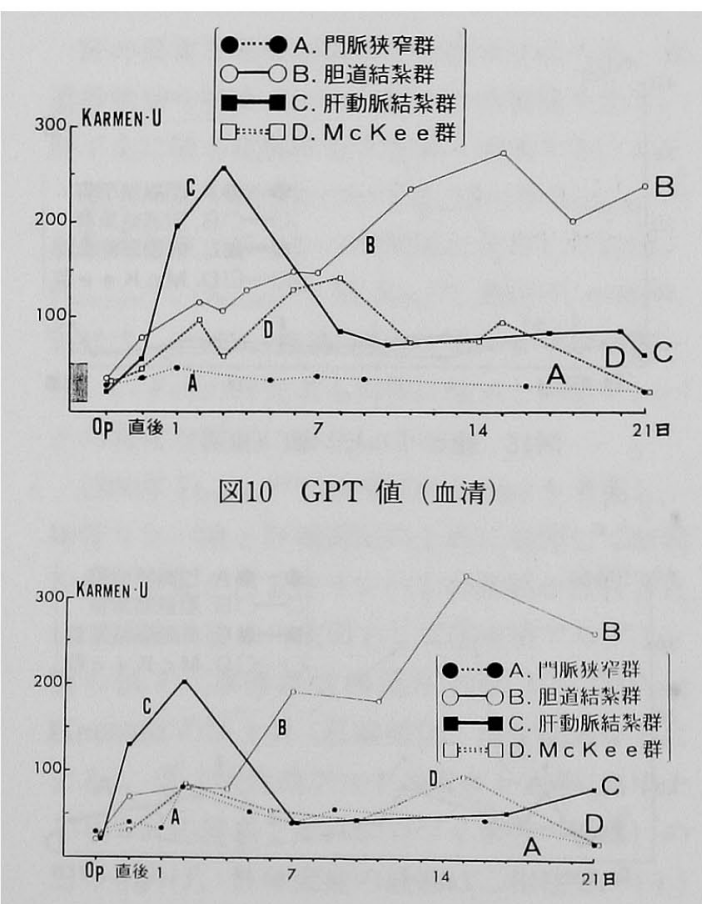

図11 GPT 值 (リンパ) 


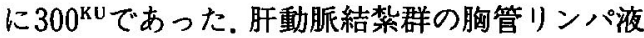
中 GPT 值は血清中と同様, 術後急速に増加し, その後急速に減少して 1 週目でほぼ術前值に復 した.

3 ）総ビリルビン值（図12，13）

総ビリルビン值は血清中よりも胸管リンパ液 中における変動が大きく，また早期に変動が生 じた，血清総ビリルビン值は門脈狭窄群，肝動 脈結禁群, McKee 群はいずれも大きく変動せず, ほぼ0.5mg/dl以下であった. 胆道結紮群では,

術後 1 週までかなり急速に增加し，その後も漸 增して 2 週目に $3.5 \mathrm{mg} / \mathrm{d} 1$ に達し 3 週目まで続い た．胸管リンパ液中の総ビリルビン值は門脈狭 窄群, 肝動脈結㮡群, McKee 群では血清ビリル ビン值より高值で, 最高値は $1.5 \mathrm{mg} / \mathrm{dl}$ であった。 これら三群の中では, 門脈狭窄群が最も高值で あった，胆道結紮群では，術直後に血清ビリル ビン值はまだ $0.3 \mathrm{mg} / \mathrm{dl}$ であったが胸管りンパ液 中ではすでに $1.0 \mathrm{mg} / \mathrm{dl}$ に増加し，その後も増加 を続け， 3 日目より急增し 4 日目には $3.0 \mathrm{mg} / \mathrm{dl}$ に達した。この高値が約 1 週間持続した後，11 日目頃から減少して $2.0 \mathrm{mg} / \mathrm{dl}$ となり，3週目ま で持続した．したがって胸管リンバ液中では血

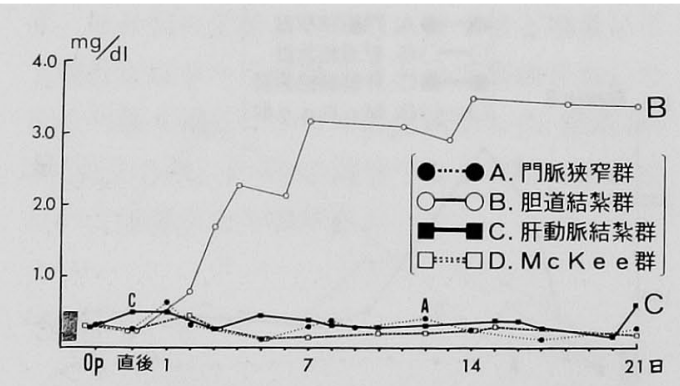

図12＼cjkstart総ビリルビン値（血清）

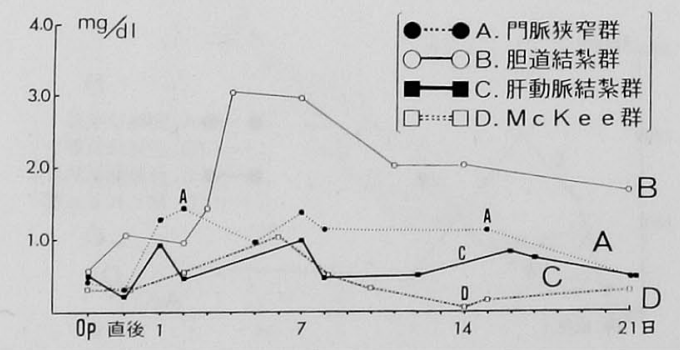

図13綕ビリルビン值（リンパ）
清に先だって增加し，血清中で著明に増加する 1〜2 週目頃には, 胸管リンパ液中のビリルビ ン值は減少しはじめた.

4) アルカリフォスファターゼ值

(Al-P, 図14，15)

血清中でも胸管リンパ液中でも Al-P 值はほと んど同様の変動を示した. 胆道結禁群以外では, 肝動脈結紮群で血清中, リンパ液中とも約 $20^{\mathrm{KAU}}$ 程度の高值を示したのみで他はほとんど変動し なかった. 胆道結禁群は, 術直後は増加せず, 術後 2 日目より急速に増加し, 血清中では 3 日

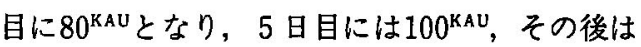
すべて100以上となった. したがって Al-Pはリ ンパ液中より，血清中の方が $1 ３$ 日早く現れ ることになった。肝動脈結紮群では術後約 3 日

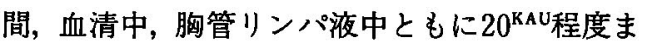
で一過性に増加した。

5) ZTT 值 (図16,17)

血清中でも胸管リンパ液中でもすべて正常範 囲内の変動であったが，血清中よりもリンパ液 中で変動が大きかった，血清中では，胆道結紮

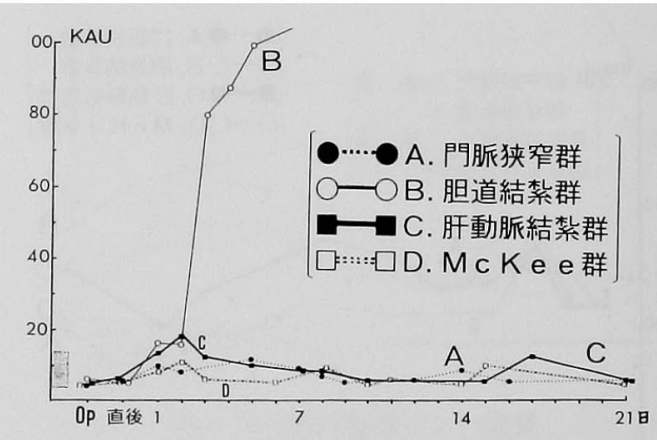

図14 アルカリフォスファターゼ值（血清）

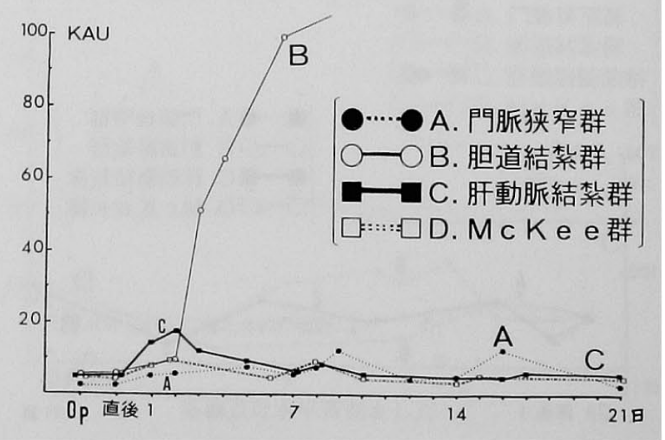

図15 アルカリフォスファターゼ値（リンパ） 
群で術後 2 週の間漸増して, $4.5^{\mathrm{V}}$ に達し, その後 低下して 3 週目には 2.5 になった. 胸管りンパ液 中の ZTT 值は, 肝動脈結紮群, McKee 群で術

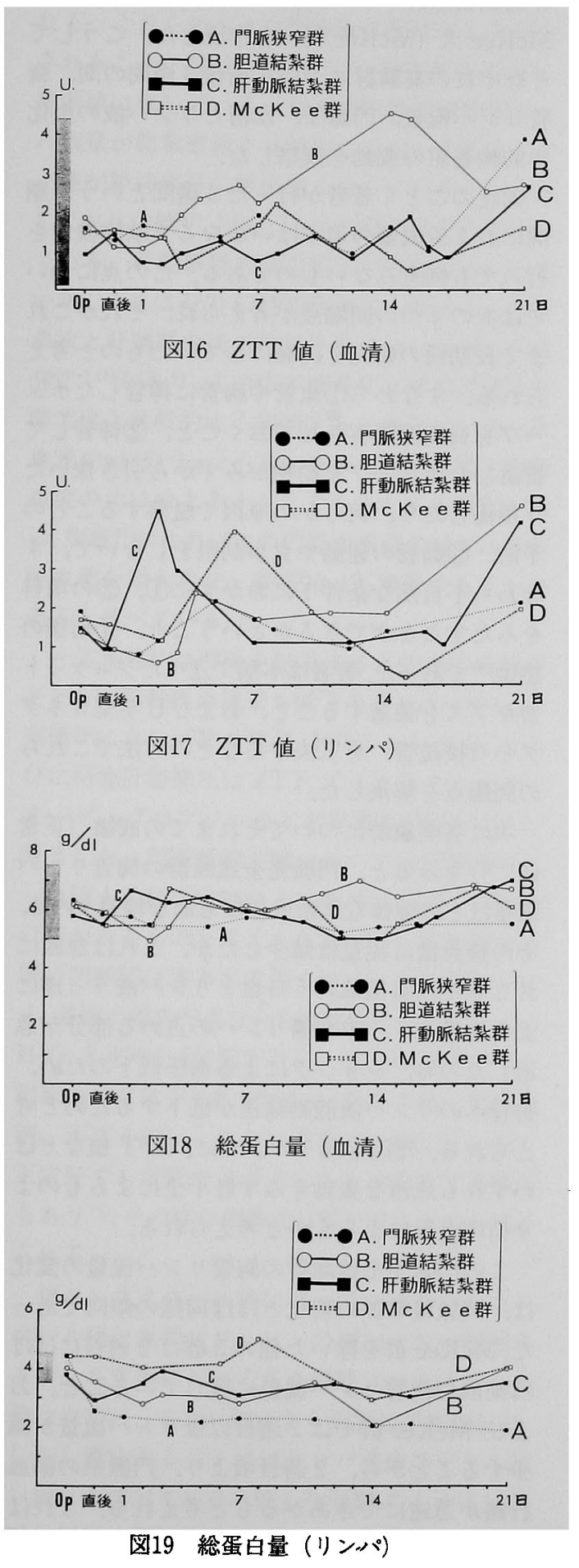

後それぞれ 2 日，6 日目に約 4 と上昇し，さら に胆道結紮群と肝動脈結紮群は 3 週目に $4 \sim 5$ 山 まで上䄯したが，一定の傾向は示さなかった。 血清 ZTT 值とリンパ液中 ZTT 值との相関はみ られなかったが, どの実験群も 3 週目には血清 中,リンパ液中ともに上昇傾向を示した。

6 ）総蛋白量 (図18,19)

血清総蛋白量はどの実験群も術後 3 週の間, ほとんど変動せず，胸管リンパ液中では門脈狭 窄群で術前値4.5から術直後2.5に低下したま， 3 週間持続した. 胆道結䕀群, 肝動脈結柇群も 術後軽度 (3.0) に低下したが 1 週以内に回復傾 向を示した. McKee 群は 8 日目に 5.0 と軽度增 加したが後はほとんど正常範囲内であった。し たがって門脈狭窄群では術後約 2 週間, 胸管り ンパ流量の增加をみたが, それは蛋白濃度の低 いリンパ液であった。他群についてみると, 門 脈狭窄群, 胆道結䅨群, 肝動脈結紮群は胸管リ ンパ流量の増加と，そのリンパ液中蛋白濃度と は逆相関の関係にあるといえる.McKee 群では 著明に増加した胸管リンパ液中には比較的高濃 度 $(4.0 \mathrm{~g} / \mathrm{dl}$ 前後) の蛋白を含んでいた。

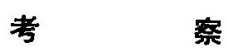

肝の異常な循環状態下では腹水をはじめ，食 道静脈瘤や黄疸といった様々の病態像を生じ, 肝不全に陥る症例にもとき扔り遭遇する。

腹水の発生機序については, 1894年 $\mathrm{S}_{\text {TARLING }}{ }^{120)}$ が腹水生成と肝リンパの関係に注目して以後, $P_{\text {ICKERT }}{ }^{13)}, \mathrm{O}_{\mathrm{RLOFF}}{ }^{151}, \mathrm{M}_{\mathrm{C}} \mathrm{K}_{\mathrm{EE}}{ }^{14)}$, 越川12), 小林 ${ }^{10)}$, 志村 ${ }^{11)}$, 三辺 ${ }^{8)}$, 島田9)他, 枚挙にいとまがない が，いずれの研究者も同様に腹水と胸管リンパ との密接な関係に言及している.

1960 年 $\mathrm{D}_{\mathrm{UMONT}}{ }^{37}$ は胸管 Drainage を考案し， 胸管リンハ液と肝類洞圧の上昇に起因して類洞 近傍で生成される肝リンパとの関係が注目され た.三辺 ${ }^{8}$ は腹水の成因として(1)血清アルブミン 值の低下（血漿膠質渗透圧の低下), (2) Post Sinusoid の圧上昇（肝線維化，再生結節などに よる), (3)二次性高アルドステロン血症 (血中ナ トリウムの停滞とそれにつづく水分の停滞) の 三つをあげ，肝硬変症の経過は二相性で，（i ） 初期には, 類洞の透過性元進, 肝リンパの過剩 
生成による胸管リンパ流量の増大，（ii）その後 進行すれば肝内血行路, リンパ路の障害が著明 となり胸管リンパ流量はむしろ減少しリンパ 床の capacityを越えた肝リンパの肝被膜からの 漏出がおこり，腹水が生ずるとした $\mathrm{S}_{\text {CHRE1BER }}$ (1967)の説を引用している. 島田9/は肝硬変症 では肝内線維化・再生結節が肝静脈起始部を圧 迫し，血流抵抗をつくるため類洞压と門脈圧と が上昇し, 肝リンパの増量が生じ, アルブミン 合量が高く，渗透圧の高い肝リンバ液の腹腔内 漏出により,さらに腹水としての水分移動が助 長されると述べている。

かくして肝の病態像をとらえる過程でリンパ 系の検索がなされてきたわけであるが，胸管り ンパに関する研究は高橋26), $\mathrm{D}_{\text {UMONT }}{ }^{36 \text { 43) など多 }}$ 数みられる $17,25 \sim 52,60)$.

一般に胸管リンパは下肢からのリンパ（脚リ ンパ29) と腸管全体からの腸リンパ,さらに肝リン パとを包含する．正常成犬の胸管リンパ流量 (0.3〜2.6ml/分)のうち $3 / 4$ は腸リンパ，肝リン パで占められ，他の部位より $1 / 4$ 流入しているが 結局，胸管リンパ液の $50 \%$ を腸リンパ，25\%を 肝リンパ，残りの $25 \%$ を他の主として脚リンパ が占めるとされている25 32).

さて胸管リンバ液の採取または外科的治療の 一つとして胸管を利用する方法も数多くみられ た 43,53 64). しかし胸管リンパ液を同一個体から

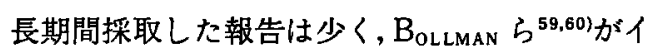
又を用いて 8 日間行っている報告以外はほとん ど数時間以内である.ラットではやはり $\mathrm{B}_{\text {OLLMAN }}{ }^{59)}$ が10日間の胸管内㨉管を継続しており，この間 の腸リンパ，胸管リンパを採取している，胸管 内のリンバ球の80 90\%は T-cell であるなどの 理由により繁移植や植皮に对して生着率を高め るために胸管リンパの処理の試みも報告されて いる年,56).

以上のごとき経緯で著者は実験的に門脈狭窄， 総胆管結皆, 肝動脈結浆, 下大静脈狭窄の 4 種 類の肝障害犬を作成し, 胸管内挿管の後, その 挿管チューブを長期間保全するための努力を行 い,これから得られる胸管リンパと血清の量的, 生化学的㭘索を行った.

まず門脈を㹟窄した場合と門脈を完全に遮断
した場合との胸管リンパの態度の差を知るため に予備実験として問脈の完全結柇を行った。つ いで A) 門脈狭窄群 B) 総胆管結紮群 C) 肝動脈結枈群 D）胸部下大静脈狭窄いわゆる McKee 犬 (McKee 群) を作成した.こうして それぞれの実験群について術後 3 週間の間, 胸 管リンパ流量, 門脈圧, 血清とリンパ液の生化 学的検查值の変動を観察した。

前述のごとく著者が行った 3 週間という長期 間におよふ成績の追求はいかなる文献的検索を 行っても例をみないものである.この点につい ては次の 4 つの問題点が考之られ，それがこれ まで長期間の研究を困難にしていたものと考え られる。すなわち(1)血管や胸管に挿管したチュ 一ブを長期間開存させておくこと，(2)挿管して 留置したチューブを動物がみずから引き抜いた り損傷したり，何らかの原因で脱落することの 予防，(3)動物の運動や食事制限をしないで，す なわち不自然な条件下におかずに(1)，(2)の項目 をみたすことができるかということ，(4)術後の 感染88)であった。著者は本稿で述べたジャケット 型ギプスを装着すること，およびU字型コネク ター（接続管）を工夫するなどの方法でこれら の問題点を解決した.

次に各実験群についてそれまでの成績（正常 值 ${ }^{1-5)}$ をみると, 門脈完全遮断群の胸管リンパ 流量はどの個体も遮断直後に急激な増量をみせ, その後急激に流量は減少したが, これは急激に おこった門脈領域のうっ血とリンバ液うっ滞に より胸管リンパ中で腸リンパの占める部分が急 増したのち, ショックによる血圧低下のため, 胸管へのリンパ液能動輸送が低下するためと考 えられる. 死因も図 5 のように, GPT 值などは いずれも急激な変動をみず肝不全によるものよ り循環虚脱によるものと考之られる。

この門脈完全遮断群の胸管リンパ流量の変化 は, 門脈狭窄群の変化とほぼ同様の傾向であっ た. McKee 群を除いた他の 3 群は 2 週目にはは ほ術前の胸管リンパ流量に復していること，お よび McKee 群では 2 週目以後リンパ流量が減 少することから，2 週目頃より，門脈系の副血 行路が急速にできあがるもと考えれる。これは 門脈副血行路が 7 日目にみられ，2 3 週では 
もっとも多くみられるとする永田 ${ }^{66)}$ の報告や伊 達 ${ }^{74) の ~} 2$ 週間で完成されるなどの報告 ${ }^{72 \sim 77) に 一 ~}$ 致する所見であるが, $\mathrm{M}_{\mathrm{C}} \mathrm{K}_{\mathrm{EE}}$ ら $^{14) の よ う に ~} 4 \sim 6$ 週後に明瞭にみとめられると述べた報告もみら れる.これらのことは門脈圧の変化からも肯定 されることでMcKee 群では 2 週目以後, 早期に 術前值に復している. 胆道結紮群では胸管リン パ流量が結紮直後より増加したが，これはリン 八路が胆汁成分の排出路となっていることを示 しており山崎27)，田中㬏も同様の所見を報告し ている.肝動脈群では門脈圧の変動はみられな

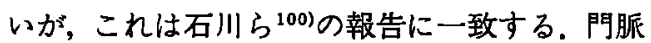
血流と肝動脈血流の相互作用について多くの研 究 ${ }^{89 \sim 118)}$ があり,この中で酒井 ${ }^{89}$ は肝血流量は肝 障害度と比較的よく相関すると報告し，また肝 血流 $40 \mathrm{ml} /$ 分 $/ \mathrm{kg}$ (イヌ) のうち門脈血流と動脈 血流の比はおよそ4：1であるとする報告が多 い.加藤昂にによればこの門脈血流量の減少は肝動 脈血流を増大させ, 最高 $90.1 \%$ 増量することが あると述べている.

一方菊池 ${ }^{91}$ は門脈を結紮すると体血压の低下 とともに肝動脈血流量も低下すると述べている. 高橋95)によれば肝血流量, 肝内シャント率, なら びに閉塞肝静脈圧は ZTT, アルカリフォスファ

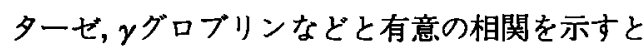
報告した。門脈狭窄実験においては門脈系のう っ血防止手段の有無により肝動脈血流への影響 に差があるものと考えられる ${ }^{91,100)}$. 肝動脈結禁 群の門脈圧は著者の成績でははとんど変動がな く,菊池の報告91)すなわち門脈圧を157から146mm $\mathrm{H}_{2} \mathrm{O}$ と平均 $6.8 \%$ 低下きせ, 体血圧は不変で, 門脈血流量は平均 $8.5 \%$ 低下 (低下 7 例, 增加 3 例, 不変 6例）したとの報告に一致しないが, 正常肝でも多数の A-P シャントが存在する個体 もあり 79),その様な個体では低下するものと考之 られる。

綕コレステロール值について：通常コレステ ロール值は血清ビリルビンの増加に伴い増加す るが、本実験においても血清総コレステロール 值は血清ビリルビン值によく相関して増加した。 しかし興味あることにはリンパ液中のビリルビ ン值は血清ビリルビン值より早期に，しかもほメ 同じ程度に増加するにもかかわらずリンパ液中
総コレステロール值は胆道結㯟群でもごくわず かしか増加せず，肝で生成されるコレステロー ルの排泄経路としてリンパ路は働らいていない ものと考えられる.これはコレステロールが親 油性であり，通常はグロブリン分画に結合して 運ばれるため6.7.119)アルブミン分画優位のリンパ 液中にはコレステロールが低値となるためであ ると考えられる。.以上より本実験の胆道結棌群 における血清総コレステロールの高值持続と， 胸管リンパ液中コレステロールの低值が理解さ れる.なお 2 週目以後血清総コレステロール值 が高値ながら漸減傾向にあるのは，胸管リンパ 液中のビリルビン值漸減傾向とよく相関するも のであり，胆汁色素の副排泄路が形成されるの が 2 週目にかけてであることと，リンパ路 がその排泄路としてよく作動しはじめることを 意味していると考えられる.

GPT 值：胆道結紮群では時間の経過とともに 血清、リンパ液中ともに増加したが,これは肝 実質障害が経時的におこっていることを示唆す る、肝動脈群は術後急速に GPT が上昇したが 一過性に急激な肝細胞障害がおこることを意味 する.ここでもリンパ夜中で，より早期に GPT 值の上昇が生じたのは，肝の冕脱酵素もまずリ ンバ路より排泄されることを示している。胆道 結紫群以外の，血管に操作を加えた群はすべて 3 週目にはほほ術前值に復するということはや はり副血行路の形成によるものと考えられる.

絵ビリルビン值：門脈狭窄群で胸管リンパ夜 中のビリルビン值が $1.5 \mathrm{mg} / \mathrm{d} 1$ 程度增加したが副 血行路の形成される 3 週目には正常值に復した。 この群でもビリルビン值は胸管リンパ液中では， 血清より先に増加し，血清より先に減少した。 これは急激な胆道閉塞においてははじめの約 1 週間が，生体に対する侵襲がもっとも大きい85-87) ため，これをリンバ路が軽減しているというこ とになる、

ここで特徴的なことは，胆道結紮群の血清ビ リルビン值および胸管リンパ液中ビリルビン值 は，ともに㓙端な高値とはならなかったことで ある.

Al-P 值：胆道結挅群で高度に增加したが, 肝

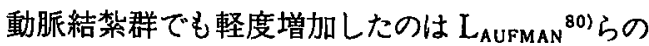


報告と一致する.この増加は肝門部の操作時に 肝動脈結杽群がもっとも強く胆道系八刺戟を加 えることに起因する可能性もあり，今後の検討

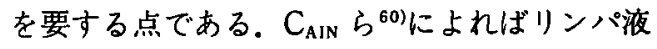
中 Al-P は血中 Al-P より 30 50\%減少してい るというが著者の成績では明らかな関係はなか った。

ZTT 值：血清 ZTT は胆道結紮群のみで比較 的高值となった（約 2 週目に最高值となった） がその理由は不明である.胸管リンハ液中の ZTT の変動は血清中での変動に比べ明らかに大きい が一定の傾向はなかった。

総蛋白量：胸管リンパ液中綕蛋白量が門脈狭 窄群で術後減少したのは胸管リンパ流量が急増 したことも一因と考えられる。胆道結禁群も胸 管リンパ流量が比較的早期に增加したからリン パ液中総蛋白量が減少したと考えられ, McKee 群では徐々に胸管リンパ流量が増加したため総 蛋白量は徐々に減少し, 副血行路完成の 3 週目 には正常值に復したと考えられる，肝の蛋白合 成能低下によるための総蛋白量の減少は明瞭で ない.

\section{結論}

肝の実験的な循環障害および胆道結紮による 閉塞性黄疸をイヌを用いて作成し，胸管リンパ 液と血清の生化学的検查他の所見を検討した結 果, 次の結論を得た.

1. 肝の循環障害および胆计排出障害時には, 血清に比し, 胸管リンパ液中で生化学的変動が より早期に現われる。

2. 総胆管結紮犬では門脈圧はほとんど上昇
しないが, 胸管リンパ流量は約 3 倍まで増加し た。これは胆汁色素が急激に肝内にうっ滞する ことを防いでいる。

3、肝動脈結禁による䦗脈圧上昇はみられな w.

4.胸管リンパ液中総コレステロール值は血 清中の約 $1 / 2$ 程度の低值である.

5. 総胆管結栤犬では血清ビリルビン值上㫒 とともに血清紷コレステロール值も增加したが， 胸管リンパ液中ビリルビン值上昇に比し，胸管 リンパ液中総コレステロール值は低值であった。 これはコレステロールがリンパ路に入りにくい ことを示唆した。

6.肝動脈結樂を行うと最初の 1 週間は, GPT 值が上昇し, 総胆管結森では 1 週間目以後 から数週間にかけ GPT 值が上昇し, 交刃型と なった。

7. 総ビリルビン值は胸管リンパ液中での変 動が大きいことから，リンパ系との関連が大で あることが示唆された。

8.U字型コネクター、ジャケット型ギプス 装着など $2 \sim 3$ の工夫を行ない，胸管内に挿管 したチューブの保全が 3 週間以上可能であるこ とを証明した。

終クに臨んで，終始御指導，御鞭䩼を賜った岡山 大学医学部第一外科学教室 折田㫫三教授, 同山大 学医療技術短期大学部 三村 久教授に深甚なる謝 意を表します。きらに研究室諸嬢の御協力に感謝い たします。

なお本論文の要旨は第20回日本消化器病学会にお いて発表した.

\section{文献}

1）日本実験動物研究会：実験動物テキスト（第一版）。東京 (1971).

2) 田嶋嘉雄：実験動物学 (各論)。朝倉書店, 東京 (1973) pp 174-184.

3）福井正信, 友田 勇, 上田雄幹：実験用ビーグルの研究. ソフトサイエンス社, 東京 (1976) pp 75-97.

4）木本誠二：実験外科ハンドブック。医学書院, 東京 (1967) pp 273-311.

5）長瀬すみ，田中寿子：実験動物の臨床生化学データ.ソフトサイエンス社, 東京 (1976) pp 159-284.

6) 吉利和也, 中尾喜久, 山形敝一, 三辺 謙, 黒岩義五郎, 織田敏次, 山村雄一：新内科学大系20. 中山書店, 東京 (1976) pp 168-173.

7 ) 吉利和也, 中尾喜久, 山形敝一, 三辺謙, 黒岩義五郎, 織田敏次, 山村雄一：新内科学大系 20 . 中山書店, 東京 (1976) $\mathrm{pp} \mathrm{3-8.}$ 
東京 (1976) pp $3-8$.

$8 ）$ 三辺 謙：肝咨患と胸腹水. 臨研 (1969) 46, 48一55.

9 ）島田宣浩：腹水の成因とその対策. 薬局（1978）29，85-90.

10）小林迪夫, 楊 総三, 䍭 元則, 小川雄一郎, 井口 潔：腹水と胸管リンパ流. 外科 (1972) 34, $571-577$.

11）志村秀彦：胸腹水の外科的治療. 臨研 (1969) 46, 96-100.

12）越川昭三：腹水. 日臨 (1972) 30，226-227.

13) Pickert H : Über Entstehung und Wesen des Aszites. Medizinische Klinik (1967) 62, 1493-1499.

14) Mckee FW, Schilling JA, Tishkoff GH and Hyatt RE : Experimental Ascites. SGO (1949) 89, 529 -539 .

15) Orloff MJ and Snyder GB : Experimental Ascites. Surgery (1961) 50, 220-230.

16）堀井五十雄：肝荗とリンパ球. 最新医（1956）11，89-97.

17）西丸和義，八田博英：肝臓と肝胹リンパ管，リンパ流，リンパ液について。最新医 (1956) 36, 97一103.

18）西村宏明：放射性ヨウ化人血清アルプミンによる肝リンパ動体の研究. 日放会誌 (1976) 36, 6-17.

19）野間口民男：人胎児ならびに哺乳動物における肝荿リンパ管系の比較解剖学的研究. 熊本医誌 (1955) 29 (補 冊第 1$)$, $118-133$.

20）島田宣浩, 小林敏成, 前田種雄, 木津裕州, 橋本宏之, 名和 伸, 系島達也：肝リンバ管に对する腹腔鏡的 研究. 肝臟 (1966) 7, 52-57.

21）奥平雅彦：肝リンパの流路. 医の歩み（1950）69，256-257.

22) Horace DR : Flow of lymph from the canine liver. Am J Physiol (1959) 196, $105-109$.

23）田路良博：胸管あるいは後腹膜リンパ系の通過障害におけるリンパ系のレ線学的研究. 日放会誌 (1969) 29, 12-32.

24）師田 昇：外科的侵裝時の血管系物質吸収能変化に関する実験的研究. 東京医学雑誌 (1959) 67,600一630.

25) Bede $M$ : The Hepatic and Intestinal Contributions to the Thoracic Duct Lymph. Qua J Exp Biol (1956) $41,318-325$.

26）高橋 淳：実験的肝 Out flow blockにおけるリンパの変化. 日消病会誌（1969）66, 53-65.

27）山崎善弥：腹水症, 胆道閉塞症と肝内外リンパ系の関係について. 日外会誌 (1965) 66, 1931-1955.

28）鈴木雅洲，渡部 㑆：胸管リンパの基礎と臨床. 綜合臨（1969）18，1976-1982.

29）八田博英：リンパ管およU゙リンパ液の流れ（I）。広島医（1960）13，15-19.

30）八田博英：リンパ管およU゙リンパ液の流れ(II). 広島医（1960）13，11-17.

31）八田博英：リンパ管およびリンバ液の流れ(III). 広島医 (1960) 13，11-20.

32）八田博英, 岡田乾一：リンパ生成における肝臓の役割について。 日生理誌（1954）16, 629-630.

33） 入沢 宏：リンパ液. 綜合医学 (1955) 12, 27-32.

34）水沢英甫：Esveriven の胸管リンパ流增大作用. 現代の臨床（1968） 2，116-118.

35）岡田乾一：Ringer 氏液静脈注入の右リンパ総管リンパへの影響について。広島医原著号（1954）2，114 -117 .

36) Dumont AE, Witte CL, Witte $\mathrm{MH}$ and William RC : Origin of Red Blood Cells in Thoracic Duct Lymph in Hepatic Cirrhosis. Ann Surg (1970) 171, $1-8$.

37) Dumont AE and Mulholland JH : Flow Rate and Composition of Thoracic Duct Lymph in Patients with Cirrhosis. N Engl J Med (1960) 263, 471-474.

38) Dumont AE, Doubilet $\mathrm{H}$, Witte CL and Mulholland JH : Disorders of the Biliary-Pancreatic System. Ann Surg (1961) 153, 774-780.

39) Dumont AE : Experimental biliary obstruction. Am J Pysiol (1962) 202, 704-706.

40) Dumont $\mathrm{AE}$ and Witte $\mathrm{MH}$ : Contrasting Patterns of Thoracic Duct Lymph Formation in Hepatic 
Cirrhosis. SGO (1966) 104, 524-528.

41) Dumont AE, Witte CL and Witte MH : Studies of Lymph in Certain Disorders of the Liver, Pancreas and Small Intestine. Am J Gastroenterol (1971) 56, 346-351.

42) Dumont AE : Icteric Thoracic Duct Lymph. Ann Surg (1973) 178, 53-58.

43) Dumont AE and Mulholland JH : Effect of thoracic duct to esophagus shunt in dogs with vena caval constriction. Am J Physiol (1963) 204, 289-290.

44) Nix JT, Mann FC, Bollman JL, Grindlay JH and Flock EV : Alterations of Protein Constituents of Lymph by Specific Injury to the Liver. Am J Physiol (1951) 164, 119-122.

45) Niels $M$, O'Keefe $D$ and Welch CS : Thoracic duct lymph flow with variations in hepatic hemodynamics. Surgery (1964) 56, 1121-1128.

46）千野宗之進：流血中および胸管リンパ液中腫湟細胞の検索。日外会誌（1969）70，1615-1642.

47）曲田公光：頸部遊清術における頸部胸管の形態に関する臨床的研究. 日耳鼻（1969）72，106一121.

48) Takashima : Lymphatico-venous communications and lymph reflex after thoracic duct obstruction. Invest Radiol (1966) 1, 188-197.

49) Takashima : Experimental Thoracic Duct Obstruction in Dogs. Jpn Circ J (1970) 34, 387.

50）向尾軍平：人および哺乳動物における胸管起始ならびにこれに関与するリンバ管系について. 熊本医会誌. (1954) 28, 790-801.

51) Lee FC: The establishment of collateral circulation following ligation of the thoracic duct. BullJohns Hopkins Hospital (1922) 33, 21.

52) Cremer $\mathrm{H}$, Müller $\mathrm{N}$ and Bechtelsheimer $\mathrm{H}$ : Morphological Studies on the Rat Liver and a Biochemical Analysis of the Serum Following Experimental Ligature of the Thoracic Duct. Lymphology (1974) 7, 69-80.

53）山田 乔：ダイコクネズミ胸管より持続的多量リンバ球採取法. 医のあゆみ（1966）56，234-238.

54）有松祥雄, 谷川久一，奥田邦雄：ダイコクネズミの胸管リンバ採取法. 医のあゆ (1969) 69，535-537.

55）庵原昭一，綿貫重雄，奥井勝二，岩瀨舟夫，千野宗之進，原 久弥，藤田昌宏，伊藤文雄，香西 裹：胸管 内リンパ液の採取法と細胞診。日臨細胞会誌（1967）6，4-5.

56）正岡 昭：胸管ドレナージ. 胸部外科 (1977) 30，608-611.

57) Inokuchi $K$ and Kusaba $A$ : Thoracic Duct-Jugular Venous Anastomosis for Intractable Hepatic Ascites or Terminal Stage of Cirrhosis : in Atlas of Applied Vascular Surgery (1976) 148-152.

58) Kawai $T$, Stoitchcov E, Lorenzini $C$, Merle $M$ and Benichoux $R$ : Long-Term Follow-Up of Dogs, with a Patent Anastomosis of the Thoracic Duct to the Esophagus. Eur Surg Res (1974) 6, 46-55.

59) Bollman JL : Techniques for the Collection of Lymph from the Liver, Small Intestine or Thoracic Duct of the Rat. J Lab Clin Med (1948) 33, 1349-1352.

60) Cain JC, Grindlay JH, Bollman JL, Flock EV and Mann FC : Lymph from Liver and Thoracic Duct. SGO (1947) 85, 559-562.

61) Wegria R, Zekert H, Walter KE, Entrup RW, Schreyver CD, Kennedy W and Paiewonsky D : Effect of systemic venons pressure on drainage of lymph from thoracic duct. Am J Physiol (1963) 204, 284-288.

62) Clauss RH and Breed ES : Controlled Rate of Drainage of Thoracic Duct Lymph. Am J Surg (1970) $119, \quad 610-612$.

63) Raju S : Technic for the Creation of a Thoracic Fistula in the Dog. Am J Surg (1974) 127, 256-257.

64) Ellis FG : A technique for intermittent collection of thoracic duct lymph. Surgery (1966) 60, 12511253. 
65）土井淳愛：実験的門脈圧六進症における腹水形成に関与するリンパ采の役割について．日消病会誌（1965） 62, 631-654.

66）永田 弘：肝前性門脈狭窄時における門脈副血行路形成に関寸る実験的研究. 名医学 (1957) 73,691一731.

67）上原従正：門脈圧六進症の発生原因に関する研究. 肝荿（1972）13，606-615.

68）江崎治夫：門脈圧六進症について。広島医（1960）13，1-10.

69）芝山雄老：コリン欠乏性肝硬変ラットにおける門脈圧六進の発生原因. 肝贜（1975）16，10-18.

70) Witte CL : Lymph Protein in Hepatic Cirrhosis and Experimental Hepatic and Portal Venons Hypertention. Ann Surg (1968) 168, 567-577.

71）比田井耕, 島 文夫, 市原荘六, 二川俊二, 杉浦光雄, 石田正統：門脈圧元進症. 綜合臨 (1974) 23, 1019 -1026 .

72）齐藤秀偉：いわゆる肝静脈閉塞症に对する門脈側副血行路造設手術法に関する研究. 名医学 (1958) 76, 56 -71 .

73）飯田 豊：胸腔内下大静脈急性閉塞に関する実験的研究. 岡山医誌（1958） $71,1145-1153$.

74）伊達政照：門脈再建に関する実験的研究。 日外宝 (1960) 29，1667-1689.

75）森野 勝：門脈再建に関する実験的研究. 日外宝 (1961) 30，1-19.

76）日置康生：門脈移植に関する実験的研究. 大阪大医誌 (1977) $36,37-53$.

77）西本勝美：門脈再建に関する実験的研究。 日外宝 (1960) 29, 1692-1709.

78）大歳栄一，水本龍二，本庄一夫：肝切除と肝動脈遮断. 日外宝（1977）46，681-688.

79) Fraser D, Rappaport AM, Vuylsteke CA and Colwell AR : Effect of the Ligation of the Hepatic Artery in Dogs. Surgery (1951) 30, 624-640.

80) Laufman H : Graded Hepatic Arterial Ligations in Experimental Ascites. SGO (1953) 96, 409-419.

81) Lee YN : Liver Function Tests After Ligation of Hepatic Artery. J Surg Oncol (1978) 10, 305-320.

82) Hőckerstedt K : Liver Hilus Dearterialization. Ann Chir Gynaecol (1978) 67, 217-223.

83）田中幹夫：肝外閉塞性黄㾝発生におけるリンパ系の関与. 肝臟（1966） 7，58-65.

84）岸 明宏：先天性胆道閉鎖症の外科治療に関する研究. 広島大医誌 (1974) 22, 213-250.

85）林慎一郎, 平松誠子：胆管醅素の血中上昇の機序. 肝臓 (1973) $14,36-39$.

86) Witte MH, Dumont AE and Levine N : Patterns of Distribution of Sulfobromophthalein in Lymph and Blood during Obstruction to Bile Flow. Am J Surg (1968) 115, 69-74.

87) Aronsen $\mathrm{KF}$ : Liver Function studies during and after complete extrahepatic biliary obstruction in the dog. Acta Chir Scand (1961) 275, 1.

88) Romieu $C$ and Brunschwig A : Bacteriologic study of the human liver. Surgery (1951) 30, 621-623.

89）酒井昭義：肝循環動態に関する研究. 日外会誌 (1960) 61，551-575.

90）加藤 泰：肝循環障客の実験的研究. 日外会誌 (1968) 69, 279-299.

91）菊池武雄：肝循環動隼の実験的研究. 肝葴（1969）10，219-233.

92）解良白泉：肝疾患における門脈および肝動脈血流の測定. 肝臓（1971）12，389-395.

93）川部克己, 横田 峻, 水本龍二, 本庄一夫：肝血行動態の実験的研究. 日外宝（1977）46, 551-562.

94）山本貞博：肝血流量測定と肝疾患. 訩療 (1970) 23，229-234.

95）高橋邦明：肝疾患とくに慢性肝炎に扩忛る肝循環動態に関する研究. 岩手医誌 (1971) 23，8-23.

96）寺中正昭：ショック時における肝㖑の血行動態と機能に関する研究. 日外会誌 (1978) 79，216-229.

97）島田宣浩：経腾静脈門脈カテーテル法による肝動脈，門脈血流量比の測定. 肝缄（1969）10，547-552.

98) 中田勝次：肝循環. 肝臟（1968） 9，219-227.

99）山中功二, 水本龍二, 大沢二郎, 河野有朋, 横田 峻, 本庄一夫：胆汁異常と肝血行動態の変動. 肝䑏（1973） 14, 2-5. 
100）石川兵衛, 松井宏照, 本庄 昭, 林需, 松島昭彦, 進藤敬久, 岡林正純：肝循環に関する研究. 奈良医 誌 (1975) 26, 446-451.

101) Moreno AH, Burchell AR, Reddy RV, Panke WF and Nealon TF : The Hemodynamics of portal hypertension revisited : Determinants and significance of occluded portal pressures. Surgery (1975) 77, $167-179$.

102) MacDonald AC, Marble AE and Perkins JG: Hepatic Blood Flow and Metabolism. Arch Surg (1979) 114, 616-621.

103) Burton-Opitz R: The Vascularity of the Liver. Q J Exp Physiol (1911) 4, 93-102.

104) Kock NG, Hahnloser $P$, Poding $B$ and Schenk WG : Interaction between portal venous and hepatic arterial blood flow. Surgery (1972) 72, 414-419.

105) Schenk WG, McDonald JC, McDonald K and Drapanas T : Direct Measurement of Hepatic Blood Flow in Surgical Patients. Ann Surg (1962) 156, 463-471.

106) Greenway CV and Oshiro G : Intrahepatic Distribution of Portal and Hepatic Arterial Blood Flows in Anesthetized Cat and Dogs and the Effects of Portal Occlution, Raised Venous Pressure and Histamine. J Physiol (1972) 227, 473-485.

107) Shafey OA and Hassab MA : Experimental study on hemodynamics of hepatic arterial and portal venous flow. Surgery (1968) 63, 962-965.

108) Hanson KM and Johnson PC : Local control of hepatic arterial and portal venous flows in the dog. Am J Physiol (1966) 211, 712-720.

109) Roy $C$ and Kountz $S$ : Factors influencing control of arterial circulation in the river of the dog. Am J Physiol (1963) 205, 1260-1264.

110) Takeuchi J, Kubo $T$, Tone $T$, Takada A, Kitagawa $T$ and Yoshida $H$ : Autoregulation and interaction between two vascular systems in dog liver. J Appl Physiol (1969) 27, 77-82.

111) Ternberg JL and Butcher HR : Blood-Flow Relation between Hepatic Artery and Portal Vein. Science (1965) 150, 1030-1031.

112) Ackroyd FW, Mito M and McDermott WV : Autonomic Vasomotor Controls in Hepatic Blood Flows. Am J Surg (1966) 112, 356-362.

113) Muller $W$ and Smith LL: Hepatic Arterial and Portal Venous Circulatory Changes Following Hemorrhage in the Dog. SGO (1963) 101, 753-758.

114) Price JB, McFate PA and Shaw RF : Dinamics of blood flow through the normal canine liver. Surgery (1964) 56, 1109-1120.

115) Macleod JJR and Pearce RG: The out flow of Blood from the Liver as Affected by Variations in the Condition of the Portal Vein and Hepatic Artery. Am J Physiol (1914) 35, 85-105.

116) Drapanas T, Kluge DN and Schenk WG : Measurement of Hepatic Blood Flow by BSP and by the Electromagnetic Flow meter. Surgery (1960) 48, 1017-1021.

117) Green HD, Hall LS, Sexton J and Deal CP : Autonomic vasomotor responses in the canine hepatic arterial and venous beds. Am J Physiol (1959) 196, 196-202.

118) Blalock A and Mason MF : Observations on the Blood Flow and Gaseous Metabolism of the Liver of Unanesthelized Dogs. Am J Physiol (1936) 117, 328-334.

119）山崎三省：代謝異常；病気の生化学, 中山書店, 東京 98-123.

120) Starling: The influence of mechanical factors on the lymph production. Am J Physiol (1894) 16, 224. 
Chemical and physiological changes of serum and thoracic-duct lymph in the dog with experimental obstructive jaundice and/or disorder of liver circulation

\section{Yuzo UedA}

First Department of Surgery, Okayama University Medical School, Okayama 700, Japan

(Director : Prof. K. Orita)

A long-term study on the chemical and physiological changes of serum and thoracic-duct lymph in the dog with a ligated common bile duct and/or artificial liver circulation was performed.

The influencee of ligation of the common bile duct appeared earlier in the thoracic-duct lymph than in the serum.

The portal pressure did not increase in the dog with a ligated common bile duct, but the lymph flow of the thoracic duct was 3 times that before ligation, which would prevent the rapid stagnation of bile pigment in the liver.

The portal pressure was not elevated after ligation of the hepatic artery.

The cholesterol level in the thoracic-duct lymph was about half of that in the serum.

In the dog with ligature of the common bile duct, the serum total cholesterol level was elevated with the elevation of serum bilirubin, whereas that in the lymph of the thoracic duct was not elevated with the elevation of the bilirubin level in the lymph.

These findings suggested that cholesterol would not easily enter into the lymphatic route.

The serum GPT level incrased during the first week after ligation of the hepatic artery, and decreased thereafter. However, after ligation of the common bile duct, the GPT level increased for several weeks after the first week of ligation. The pattern of GPT by both ligations seemed to be cross-crossed.

The marked change in the total bilirubin level in the lymph of the thoracic duct suggested its close relation with the lymphatic system.

It was proved possible to secure a tube into the thoracic duct for over three weeks by the use of a U-type connector and jacket-type plaster cast. 